\title{
Overview of the Role of Nurses in the Implementation of Education in Patients Hallucinations
}

\author{
Livana P. H. ${ }^{1}$, Titik Suerni ${ }^{2}$ \\ ${ }^{1}$ Ners Study Program, Kendal College of Health Sciences, Kendal, Indonesia \\ ${ }^{2}$ Regional Psychiatric Hospital Dr. Amino Gondohutomo, Kota Semarang, Central Java, Indonesia
}

Email address:

livana.ph@gmail.com (Livana P. H.)

\section{To cite this article:}

Livana P. H., Titik Suerni. Over view of the Role of Nurses in the Implementation of Educationin Patients Hallucinations. European Journal of Biophysics. Vol. 7, No. 2, 2019, pp. 43-45. doi: 10.11648/j.ejb.20190702.12

Received: June 10, 2019; Accepted: July 12, 2019; Published: September 17, 2019

\begin{abstract}
The number of individuals experiencing mental disorders every year is increasing both in Central Java and in Indonesia. Mental disorders can occur in all individuals. Individuals who have mental disorders will definitely have some limitations in meeting their daily needs Mental patients need to get the right treatment, so the role of nurses is needed especially in providing education. In implementing nursing care, nurses have roles and functions including providing health education, care givers, as family advisors, disease prevention, counseling, collaboration, ethical decision makers. The purpose of this study was to determine the role of nurses in the implementation of education in hallucinatory patients. The research using descriptive survey design. the sample of this study was nurses in Larasati's room. This research was conducted in the Larasati room of regional psychiatric hospital Dr. Amino Gondohutomo, Central Java, Indonesian in December 2017. This study used a documentation research tool derived from patient medical records. The results showed that nurses provide education to patients who experience hallucinations by helping to recognize hallucinations and symptoms and provide an implementation strategy by rebuking when the patient hears something. After the client has carried out an implementation strategy by rebuking then the patient is given medication according to the medical prescription.
\end{abstract}

Keywords: The Role of Nurses, Education, Hallucinations

\section{Background}

Mental disorder is a form of disruption and disorder of mental function or mental health caused by failure to react to the mechanism of adaptation of mental functions to external stimuli and tensions resulting in a functional disorder or disruption of the structure of a part, an organ, or mental psychiatric system. Mental disorders are spread almost evenly throughout the world, including in the Southeast Asian region. Based on data from the World Health Organization, almost one-third of the population in the Southeast Asia region has experienced neuropsychiatric disorders [1].

Based on data from Riskesdas 2007 showing the national figures of national mental disorders disorders mental emotional disorders (anxiety, depression) in the population at the age of approximately 15 years is $11.6 \%$ or about 19 million people. While with severe mental disorders on average by $0.64 \%$, about 1 million people, very little of the number of patients who come to treatment facilities. According to the calculation of mental health service utilization at the primary, secondary and tertiary levels the treatment gap is estimated to be more than $90 \%$.

In Indonesia, the Indonesian Ministry of Health (2003) notes that $70 \%$ of the biggest mental disorders are Schizophrenia. According to Arif (2006) revealed that $99 \%$ of patients treated in mental hospitals are patients with a medical diagnosis of schizophrenia. More than $90 \%$ of schizophrenic patients experience hallucinations. [1] There are two types of mental disorders that can be found in the community, namely mild mental disorders and severe mental disorders. Mild mental disorders for example are mental emotional disorders. Severe mental disorders one of which is schizophrenia. Most patients treated in mental hospitals are patients with severe mental illness schizophrenia.

Schizophrenia is a neurological disease that affects perceptions, ways of thinking, language, emotions, and patient social behavior Based on data from the APA (The 
American Psychiatric Association), in the United States there are 300 thousand schizophrenic patients who experience acute episodes every year. Schizophrenia patient mortality rates are 8 times higher than the population mortality rate in general. Schizophrenic patients who try to commit suicide as much as $20-30 \%$, and $10 \%$ of them succeed.

Stuart \& Laraia (2005) state that patients with a medical diagnosis of schizophrenia of $20 \%$ experience auditory and visual hallucinations simultaneously, $70 \%$ experience auditory hallucinations, $20 \%$ experience visual hallucinations, and $10 \%$ experience other hallucinations. [3] Based on these data it is known that the type of hallucinations that most suffer from patients with schizophrenia is hearing. Hallucinations are the most common form of sensory disturbance. Patients who experience hallucinations usually feel a false sensation in the form of sound, vision, taste, touch or smell. [4] Sensory and perceptions experienced by patients are not sourced from real life, but from the patient himself. It can be concluded that the sensory experience is a sensory of false perception.

Chaery (2009) states that the impact that can be caused by patients who experience hallucinations is losing their control. The patient will experience panic and his behavior is controlled by hallucinations. In this situation patients can commit suicide (suicide), kill other people (homicide), and even damage the environment To minimize the effects of hallucinations, proper handling is needed. With the high incidence of hallucinations, it is increasingly clear that the role of nurses is needed to help patients control their hallucinations. The role of nurses in dealing with hallucinations in hospitals includes implementing standards of nursing care, group activity therapy, and training families to treat patients with hallucinations. Nursing care standards include the application of strategies for implementing hallucinations. The implementation strategy is the application of scheduled nursing care standards that are applied to patients aimed at reducing mental nursing problems that are addressed. [5]

Implementation strategies in hallucinatory patients include activities to recognize hallucinations, teach patients to rebuke hallucinations, take medication regularly, chat with other people when hallucinations arise, and carry out scheduled activities to prevent hallucinations. [6] Carolina (2008) shows that the application of standardized nursing care can help reduce hallucinatory signs and symptoms by $14 \%$. Patients' cognitive abilities increased by $47 \%$ and psychomotor abilities by 48\%. [7] Sulastri (2018) in his study of 30 respondents found that the application of nursing care can control the patient's hallucinatory symptoms. [8]

In implementing nursing care, nurses have roles and functions as nurses including care givers, as family advocates, disease prevention, education, counseling, collaboration, ethical decision makers and researchers. [9] Role is a set of behaviors expected by others towards someone according to their position in a system. Roles are influenced by social conditions both from within and from outside and are stable. [10]
Based on the results of the study it was found that in the intervention group there was an increase in the value of the ability to control hallucinations, whereas in the control group there was no change. The results of both studies showed that there were differences in the ability of patients to control hallucinations before and after the implementation of the hallucinatory strategy.

\section{Method}

The research design used descriptive surveys The sample of this study was nurses in the Larasati room. This research was conducted in Larasati Semarang Hospital in the room in December 2017. This research uses documentation research tools, information can also be obtained through facts stored in the form of letters, diaries, photo files, meeting results, activity journals, etc. The documentation in this study comes from the patient's Medical Record.

\section{Results}

Based on a survey conducted in the Larasati room it can be seen that nurses provide education to patients who experience hallucinations by helping to recognize signs and symptoms of hallucinations and provide strategies for implementation by rebuking when patients hear something. After the client has carried out an implementation strategy by rebuking then the patient is given a medication according to a medical prescription.

Table 1. Characteristics of respondents $(n=11)$.

\begin{tabular}{lll}
\hline characteristics & f & \% \\
\hline Ages & & \\
$25-35$ & 4 & 36 \\
$36-40$ & 2 & 18 \\
$>40$ & 5 & 46 \\
Education & & \\
Diploma & 7 & 64 \\
Bachelor & 3 & 27 \\
Master & 1 & 9 \\
Gender & & \\
Man & 6 & 55 \\
Woman & 5 & 45 \\
Length of working & & \\
$<$ 5years & 3 & 27 \\
$>$ 5years & 8 & 73 \\
\hline
\end{tabular}

\section{Discussion}

Based on the results of the study, it was concluded that there was a role for nurses in the implementation of education in hallucinatory patients at Amino Hospital, gondho Hutomo. This research is in line with. [11] The results of the study show that: Listening techniques, in this technique the nurse listens to the problems, feelings and thoughts experienced by the patient, by showing attention and playing an active role. Techniques to ask in this technique the nurse asks with the aim to be able to encourage hallucinatory patients to reveal more sfesifik and complete 
information on the problems, feelings and thoughts. [12, 13]

According to Afnuhazi (2015) Based on the results of the study the results obtained, that the therapeutic communication pattern of nurses in schizophrenic mental disorders patients has stages of communication, namely the first stage of pre-interaction nurses build trust with each other with patients. [14] Second, the stage of introduction by developing interpersonal communication relationships in the form of nonverbal use, facial expressions, voice intonation, touch or a sense of empathy. Third, the stages of orientation, nurse and patient introduction continue at the stage of examining the patient's condition and evaluating the action directly. Fourth, the stages of work, the nurse interaction process and the patient can encourage the healing process of the patient. Fifth, the stages of termination of the interaction process to reduce the level of psychological distress of patients with intense communication interactions and routine treatment. In the process of nurse and patient communication interactions there are also components of interpersonal communication that play a role. The role of caregivers as educators is done by helping clients improve health knowledge, symptoms of the disease and even the actions given, so that behavior changes occur from clients and increase independence. [15] Health education is very important for a nurse. Health education is a consciously planned process, so that individuals can learn and improve their knowledge and skills for their health. [16]

\section{Conclusion}

Based on the results of a survey conducted in the Larasati room it can be seen that nurses provide education to patients who experience hallucinations by helping to recognize signs and symptoms of hallucinations and provide strategies for implementation by rebuking when patients hear something. After the client has carried out an implementation strategy by rebuking then the patient is given a medication according to a medical prescription.

\section{References}

[1] Yosep, Iyus. (2011). Keperawatan Jiwa (edisi revisi). Bandung: PT. Refika Aditama.
[2] RISKESDAS (Riset Kesehatan Dasar). (2007). Jakarta: Badan Penelitian dan Pengembangan Kesehatan, Departemen Kesehatan, Republik Indonesia.

[3] Stuart, G. W. (2013). Principles and Practice of Psychiatric Nursing. 8th edition. Missouri: Mosby.

[4] Direja, A. H. (2011). Buku Asuhan Keperawatan Jiwa. Yogyakarta: Nuha Medika

[5] Fitria, Nita, (2009), Buku Ajar Keperawatan Jiwa, Salemba Medika, Jakarta.

[6] Keliat. BA. (2010). Model Praktik Keperawatan Profesional Jiwa. Jakarta: Buku Kedokteran EGC.

[7] Carolina, Keliat, BA, Sabri, L (2008). Pengaruh Penerapan Standar Asuhan Keperawatan Halusinasi terhadap Kemampuan Klien Mengontrol Halusinasi di RS Dr. Soeharto Heerdjan Jakarta.

[8] Sulastri (2018). Kemampuan Keluarga dalam Merawat Orang dengan Gangguan Jiwa. Jurnal Kesehatan Volume 9, Nomor 1, April 2018 http://ejurnal.poltekkes-tjk.ac.id/index.php/JK

[9] Hidayat, A. A. A. (2012). Metode Penelitian Keperawatan dan Tekhnik Analisa Data. Jakarta: SalembaMedika.

[10] Kusnanto. (2009). Pengantar Profesi dan Praktik Keperawatan profesional. Jakarta: EGC.

[11] Adiansyah. (2014). Teknik Komunikasi Terapeutik Perawat Pada Pasien Halusinasi Di Rumah Sakit Jiwa. https://elib.unikom.ac.id/files/disk1/698/jbptunikompp-gdladiansyahn-34871-10-unikom_-i.pdf

[12] Sulahyuningsih, E. (2016). Pengalaman Perawat Dalam Mengimplementasikan Strategi Pelaksanaan (Sp) Tindakan Keperawatan Pada Pasien Halusinasi Di Rumah Sakit Jiwa Daerah Surakarta. (Skripsi Universitas Muhammadiyah Surakarta).

[13] Pravitasari, G, A. (2015). Gambaran Manajemen Gejala Halusinasi Pada Orang Dengan Skizofrenia (Ods) Di Ruang Rawat Inap Rsjd Dr. Amino Gondohutomo Semarang. (Skipsi Universitas Diponegoro Semarang).

[14] Afnuhazi, R., (2015). Komunikasi Terapeutik Dalam Keperawatan Jiwa. Yogyakarta: Gosyen Publishing.

[15] Hidayat, A. A. (2007). Pengantar Kebutuhan Dasar Manusia: Aplikasi, Konsep, dan Proses Keperawatan. Jakarta: Salemba Medika.

[16] Nursalam \& Efendi, F (2008). Pendidikan Dalam Keperawatan. Jakarta: Salemba Medika. 